\title{
GEOLOGIC STRUCTURAL CONTROLS ON COALBED METHANE CONTENT OF THE NO. 8 COAL SEAM, GUJIAO AREA, SHANXI, CHINA
}

\author{
XIA, P. ${ }^{1,2}-$ ZENG, F. ${ }^{1,2, *}-$ SONG, X. ${ }^{1,2}-$ LI, K. ${ }^{1}-$ WANG, J. ${ }^{1,2}-$ FENG, S. ${ }^{1,2}-$ SUN, B. ${ }^{1,2,3}$ \\ ${ }^{1}$ Department of Geoscience and Technology, Taiyuan University of Technology \\ Taiyuan 030024, China \\ ${ }^{2}$ Shanxi Key Laboratory of Coal and Coal Measures Gas Geology Exploration \\ Taiyuan 030024, China \\ ${ }^{3}$ School of Earth Science, The University of Queensland \\ Brisbane 4072, Australia \\ *Corresponding author \\ e-mail: m15735162787@163.com \\ (Received $30^{\text {th }}$ Jun 2016; accepted $12^{\text {th }}$ Oct 2016)
}

\begin{abstract}
Gas contents are highly heterogeneous in coalbed methane (CBM) reservoirs of the Gujiao area, Shanxi province, China. Diverse geologic data and stimulate methods were used to provide insight into the origin of this variability and the consequences of gas content in the No. 8 coal seam. The results show that the No. 8 coal seam experienced two gas-generating periods and one fluctuant period, and has stepped into migration period since the Late Cretaceous. The distribution of gas content of the No. 8 coal seam in the Gujiao area is mainly dominated by structural form, water level and burial depth, all of which are structural related parameters. The gas content in the subarea $\mathrm{A}$ is much lower than that in the subarea $\mathrm{B}$ because the subarea $\mathrm{A}$ is deformed severely and the subarea $\mathrm{B}$ is a gentle monocline. The gas content first increases and then decreases with increasing burial depth, and the turning burial depth is about $600.0 \mathrm{~m}$. Strong runoff area is harmful for preserving gas due to the washing effect in it. The analyzing results show that: gentle and simple monocline blocks with burial depth ranges from $500.0 \mathrm{~m}$ to $800.0 \mathrm{~m}$, water level lower than $900.0 \mathrm{~m}$ is the most important "sweet spots" for CBM development in the Gujiao area.
\end{abstract}

Keywords: coalbed methane; gas content; structural controls; Gujiao area; Xishan coal field

\section{Introduction}

With the decline in conventional natural gas reserves and increased demand and price of natural gas, industry has shown great interest in coalbed methane (CBM) resources in recent decades, which requires accurate estimation of CBM potential and recoverable reserves to assist in its development (Karacan, 2009; Zhang et al., 2010). Basin-scale investigation of the CBM resource have been performed in the Piceance and Matanuska basins in the United states (Johnson and Flores, 1998; Payne and Ortoleva, 2001), the Bowen and Sydney basins in Australia (Boreham et al., 1998; Faiz et al., 2007), and the Qinshui and Ordos basins in China (Wang et al., 2013; Cai et al., 2014). Previous reports and papers show that geologic structure is the most important control factor of reservoirs of CBM. The generation, migration and preservation of CBM during geologic history are dominated by tectonic evolution movements (Scott et al., 1994). Plutonic and thermal metamorphisms determine the gas generation (Liu et al., 2005), and the generated gas 
content continuously increases with increasing $R_{0, \max }$ (the maximum vitrinite reflectance) (Qin et al., 1997). Tectonic subsidence is helpful for preserving gas, but uplifting movement will cause the migration of gas (Song et al., 2012). Structural deformation, burial depth and hydrodynamic condition are key parameters controlling the gas distribution (Meng et al., 2014a). Despite the great number of papers and reports, important questions about controls of geologic structure on gas content remain unanswered, and what have mainly mentioned by former researchers are the distribution and evolution of gas content and permeability, which are the most important factors affecting gas production. However, previous resource evaluations haven't taken the geologic structure into consideration. Moreover, the researches of resource evaluation and geologic structure in China mainly have concentrated in the famous southern Qinshui basin (SQB) and eastern Ordos basin (EOB) (Lv et al., 2012; Meng et al., 2014b; Zhao et al., 2015). Related research is necessary but absent in many CBM-producing basins in China, especially in the Xishan coal field (XCF).

Compared with the SQB and EOB, the XCF has very short CBM exploration and development history (the CBM development was started in 2011) and much more complicate structural conditions, in which Gujiao is the only one area has been put into CBM development (Wang et al., 2015a). However, the CBM development in the Gujiao area is unsuccessful (the average gas production is about $277 \mathrm{~m}^{3} / \mathrm{d}$ per well) due to its' complicate geologic structure and the absent of resource evaluation (Xia et al., 2016).

Herein, the effects of geologic structure on the distribution of the gas content in the No. 8 coal seam were analyzed based on the coal core testing data, logging interpretation results, coalmine geology data, field geology data and water chemical measurements. Then the favorable geologic structural conditions for preserving gas were recognized. This study will be helpful for the CBM development, and will give instructions for adjustment of CBM development plan in the Gujiao area.

\section{Geologic background}

The XCF (Figure 1), located in the center of Shanxi province, China, extends eastward into the Lvliang uplift, westward into the Taiyuan fault depression, northward into the Wutai mountain and southward into the Jinzhong fault depression. The XCF subjected to four orogenies; the Indosinian, Early Yanshanian, Late Yanshanian and Himalayanian orogenies (Wang et al., 2007). The Pennsylvania Taiyuan and Permian Shanxi Formations are the main coal-bearing strata (Figure 2) in the XCF. The Gujiao area, distributed in the northwest of the XCF, is the only area put into CBM development. The No. 8 coal seam in the Taiyuan formation is the primary target zone for CBM development with a thickness range of $0.56 \mathrm{~m}-4.95 \mathrm{~m}$ (the average is $3.15 \mathrm{~m}$ ), burial depth is $180.6 \mathrm{~m}-905.8 \mathrm{~m}$ (the average is $611.1 \mathrm{~m})$, maximum vitrinite reflectance $\left(\mathrm{R}_{\mathrm{o}, \max }\right)$ is $1.23 \%-2.22 \%$. The gas content of the No. 8 coal seam ranges from $4.0 \mathrm{~m}^{3} / \mathrm{t}$ to $16.5 \mathrm{~m}^{3} / \mathrm{t}$, and the $\mathrm{CH}_{4}$ concentration changes between $79.34 \%$ and $99.34 \%$ (Pang et al., 2015). 


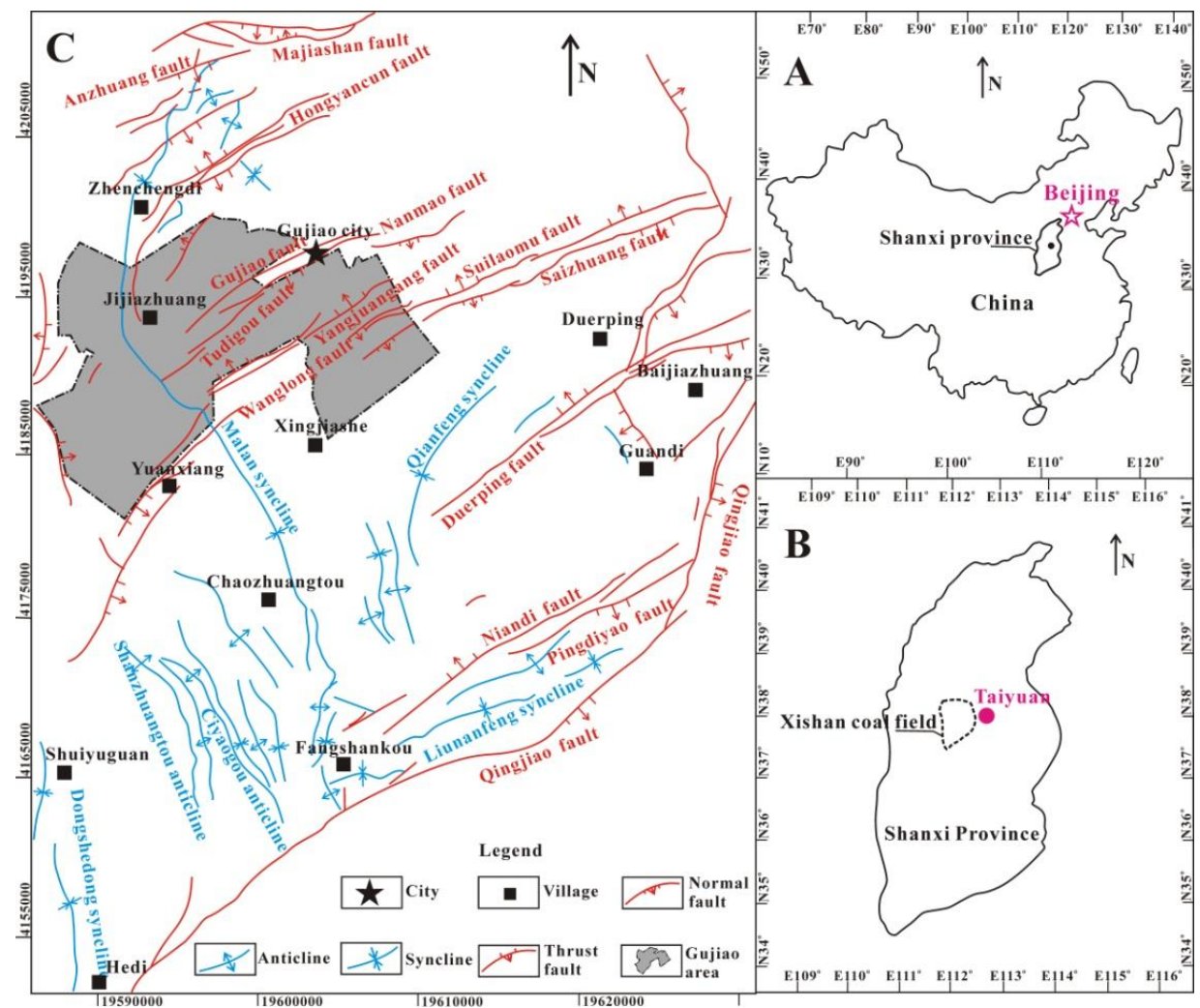

Figure 1. Study area. (A) Location of Shanxi province in China. (B) Location of the XCF in Shanxi province. $(C)$ Location of the Gujiao area in the XCF.

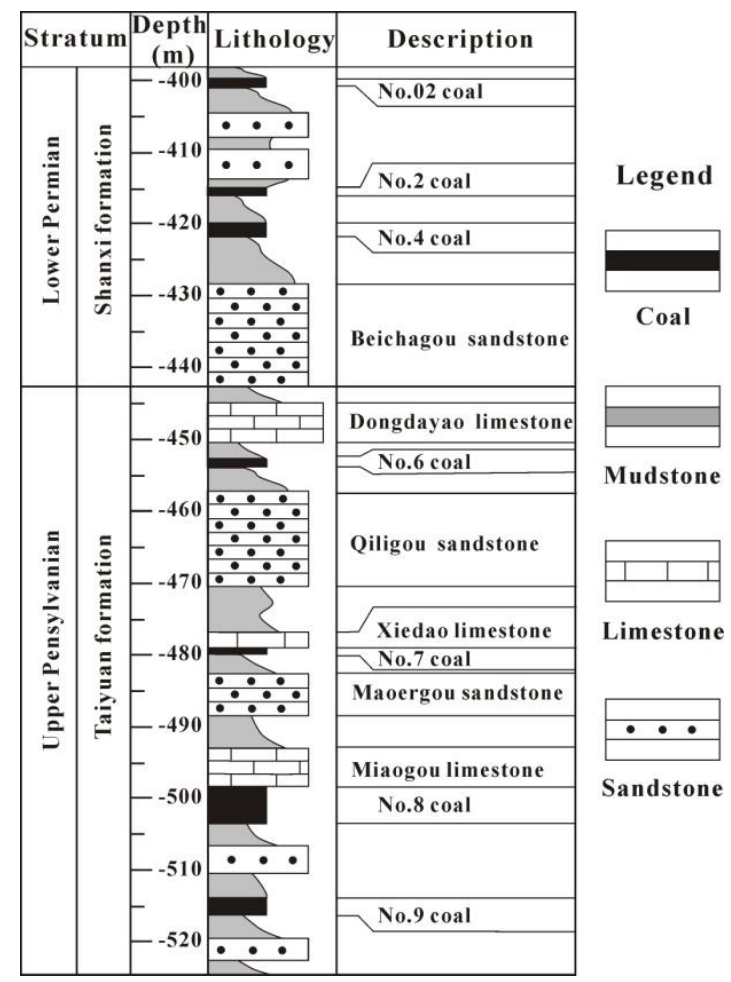

Figure 2. Lithology column of the coal-bearing formations in the Gujiao area, XCF. 


\section{Samples and experiments}

A total of 45 core coal samples were collected from the No. 8 coal seam from 45 CBM wells in the Gujiao area following the Chinese National Standard GB/T 19222-2003 (Figure 3). The samples were immediately sealed up in desorption canisters, in which the coalbed gas naturally desorbed from the coal matrix surface. The volume and composition of the desorbed gas were measured following the Chinese National Standards GB/T 19559-2008 and GB/T 13610-2003, respectively. The methane isothermal adsorption experiment and the maximum vitrinite reflectance $\left(\mathrm{R}_{\mathrm{o}, \max }\right)$ test of 3 coal core samples (E006, C046 and W195) were conducted using isothermal adsorption and desorption instruments IS-300 following the Chinese National Standard GB/T 19560-2004, and using polarizing microscope Leica DM4500P following the Chinese National Standard GB/T 6948-1998, respectively. Moreover, 30 produced water samples were collected from $30 \mathrm{CBM}$ wells in the Gujiao area. Considering the comparability between gas distribution and water composition, many water sampling points were coincident with the coal core sampling points. The water sample containers were carefully washed more than 3 times before collecting water. The water samples were immediately sent to laboratory to measure their chemical composition. Finally, the body structure of the No. 8 coal seam were observed and described in active underground coalmines in the Gujiao area (Figure 4). All testing results are documented in Table 1 to Table 3.

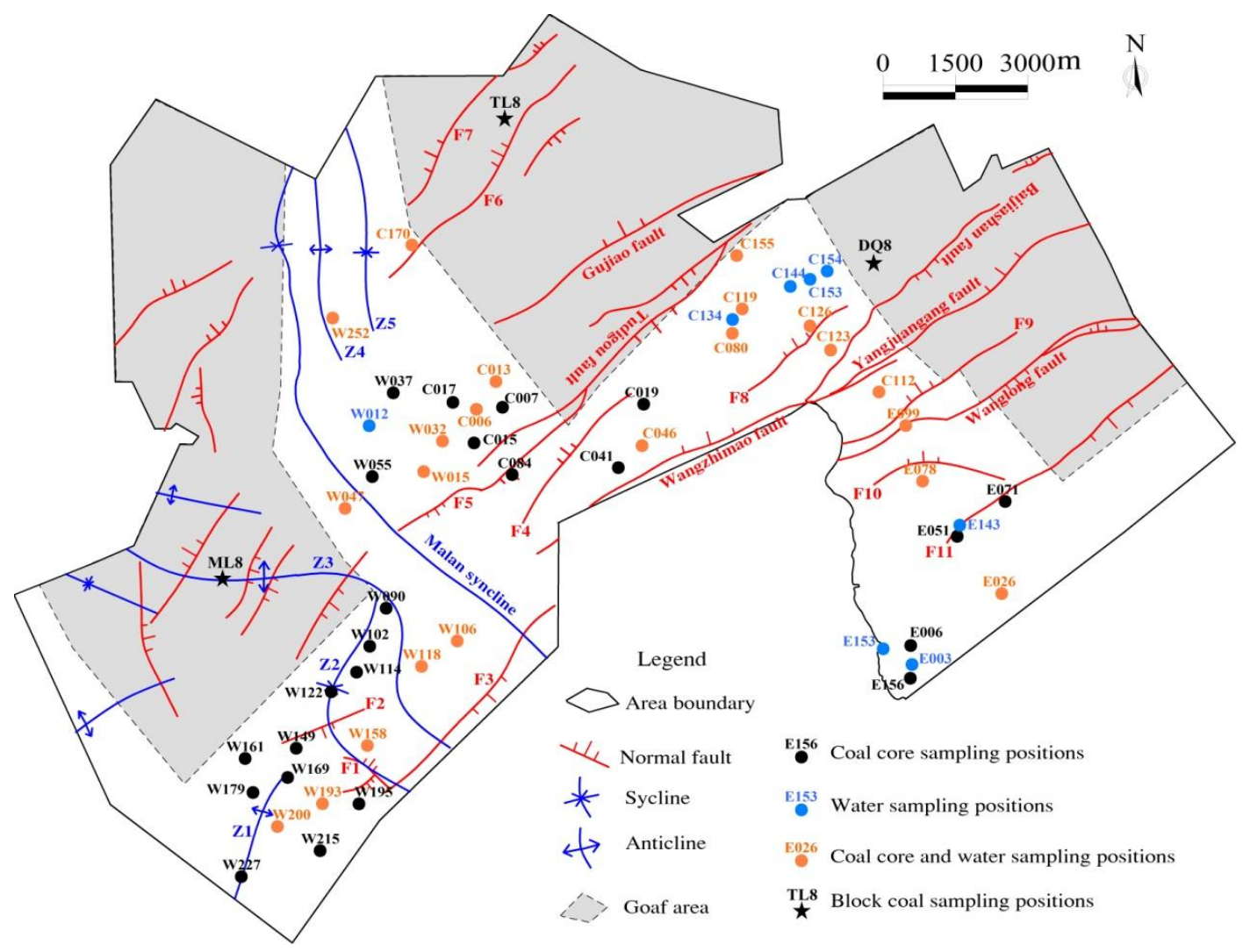

Figure 3. Structural sketch of the Gujiao area showing sampling points. 


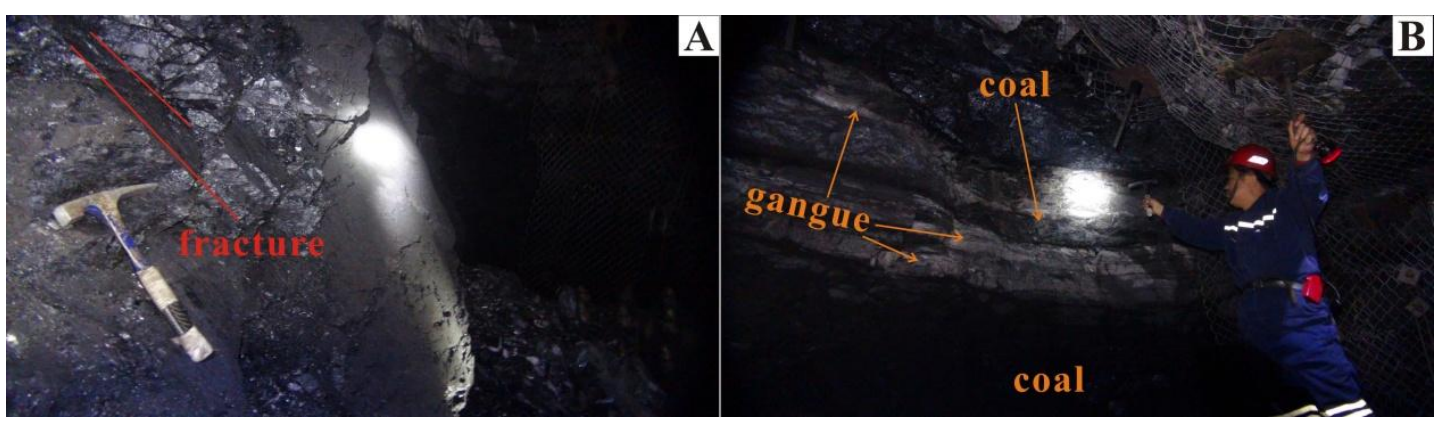

Figure 4. The photos of coal seams took in underground coalmines by anti-explosion camera (the person in B is Prof. Xiaoxia Song, who is a co-author of this work).

Table 1. Burial depth, gas content and gas composition of the No. 8 coal seam in the Gujiao area

\begin{tabular}{|c|c|c|c|c|c|c|c|c|}
\hline \multirow{2}{*}{$\begin{array}{c}\text { Sample } \\
\text { ID. }\end{array}$} & \multirow{2}{*}{$\begin{array}{c}\text { Burial } \\
\text { depth } \\
(\mathrm{m})\end{array}$} & \multirow{2}{*}{$\begin{array}{c}\text { Gas } \\
\text { content } \\
\left(\mathrm{m}^{3} / \mathrm{t}\right)\end{array}$} & \multicolumn{3}{|c|}{ Proximate analysis (\%) } & \multicolumn{3}{|c|}{ Gas composition (\%) } \\
\hline & & & $\mathrm{M}_{\mathrm{ad}}$ & $\mathrm{A}_{\mathrm{ad}}$ & $\mathrm{V}_{\mathrm{ad}}$ & $\mathrm{N}_{2}$ & $\mathrm{CO}_{2}$ & $\mathrm{CH}_{4}$ \\
\hline E006 & 483.8 & 7.9 & 1.02 & 36.13 & 20.14 & 2.01 & 0.28 & 97.71 \\
\hline E026 & 564.1 & 10.2 & 0.66 & 23.47 & 18.39 & 5.26 & 2.26 & 91.81 \\
\hline E051 & 502.5 & 12.4 & 0.49 & 11.53 & 14.23 & 5.69 & 1.11 & 93.2 \\
\hline E071 & 452.1 & 9.8 & 0.51 & 22.21 & 17.59 & 0.99 & 0.53 & 97.91 \\
\hline E078 & 444.4 & 7.6 & 0.72 & 30.17 & 17.87 & 17.31 & 0.53 & 82.15 \\
\hline E099 & 554.5 & 12.2 & 0.58 & 19.94 & 16.01 & 6 & 1.42 & 92.58 \\
\hline E156 & 473.9 & 9.2 & 0.64 & 19.49 & 17.95 & 2.6 & 0.28 & 97.12 \\
\hline W015 & 785.5 & 12.2 & 0.83 & 10.36 & 19.25 & 0.84 & 1.61 & 97.55 \\
\hline W032 & 853.7 & 12.2 & 0.6 & 14.39 & 18.58 & 3.09 & 1.8 & 95.11 \\
\hline W037 & 859.6 & 4.8 & 0.58 & 19.61 & 23.11 & 9.1 & 1.42 & 88.32 \\
\hline W047 & 773.7 & 5.4 & 0.7 & 35.26 & 25.15 & 12.62 & 1.46 & 85.39 \\
\hline W055 & 830.9 & 5.5 & 0.58 & 13.25 & 23.42 & 9.93 & 2.02 & 85.55 \\
\hline W090 & 491.7 & 9.6 & 0.56 & 15.19 & 22.87 & 3.98 & 0.54 & 95.48 \\
\hline W102 & 556.6 & 5.1 & 0.92 & 38.12 & 26.16 & 9.73 & 1.33 & 86.03 \\
\hline W106 & 709.7 & 4.1 & 0.53 & 47.03 & 27.48 & 23.43 & 1.63 & 74.94 \\
\hline W114 & 565.3 & 5.5 & 0.54 & 14.84 & 22.23 & 2.83 & 1.05 & 96.12 \\
\hline W118 & 615.4 & 8.1 & 0.9 & 26.28 & 22.46 & 0.98 & 0.44 & 98.42 \\
\hline W122 & 651.3 & 7.4 & 0.84 & 20.85 & 24.53 & 19.11 & 1.5 & 79.34 \\
\hline W149 & 620.6 & 6.4 & 0.75 & 6.43 & 18.93 & 11.05 & 0.74 & 87.95 \\
\hline W158 & 681.1 & 6.2 & 0.76 & 26.69 & 22.69 & 15.46 & 2.03 & 81.31 \\
\hline W161 & 546.2 & 5.0 & 0.54 & 36.64 & 25.34 & 10.44 & 0.85 & 88.55 \\
\hline W169 & 673.2 & 6.6 & 0.82 & 24.02 & 19.94 & 5.42 & 0.67 & 93.91 \\
\hline W179 & 576.3 & 4.9 & 0.87 & 24.85 & 17.36 & 9.89 & 0.74 & 87.65 \\
\hline W193 & 644.5 & 7.9 & 0.74 & 21.27 & 19.09 & 4.85 & 1.72 & 93.3 \\
\hline W195 & 699.2 & 10.3 & 0.82 & 10.26 & 18.63 & 1.86 & 0.52 & 93.34 \\
\hline W200 & 653.7 & 4.3 & 0.75 & 31.84 & 18.39 & $\mathrm{x}$ & $\mathrm{x}$ & $\mathrm{x}$ \\
\hline
\end{tabular}




\begin{tabular}{ccccccccc} 
W215 & 598.8 & 6.5 & 0.86 & 20.85 & 15.98 & 20.89 & 1.22 & 77.79 \\
W227 & 428.8 & 5.4 & 1.25 & 25.64 & 11.93 & 2.21 & 0.33 & 97.32 \\
W252 & 460.5 & 8.1 & 0.68 & 8.39 & 23.72 & 6.84 & 0.82 & 92.34 \\
C006 & 783.0 & 9.9 & 0.4 & 11.22 & 21.14 & 5.59 & 1.51 & 92.9 \\
C007 & 760.4 & 12.5 & 0.48 & 15.61 & 19.6 & 0.4 & 1.1 & 98.5 \\
C013 & 716.2 & 13.1 & 0.41 & 14.82 & 18.48 & 0.94 & 1.04 & 98.02 \\
C015 & 751.5 & 10.2 & 0.76 & 31.09 & 22.01 & 14.02 & 1.73 & 84.26 \\
C017 & 802.5 & 12.2 & 0.72 & 12.24 & 18.74 & 1.46 & 1.42 & 96.98 \\
C019 & 610.0 & 16.1 & 0.66 & 25.97 & 18.63 & 4.79 & 1.13 & 93.93 \\
C041 & 680.0 & 15.4 & 0.59 & 12.26 & 17.23 & 11.13 & 1.07 & 87.79 \\
C046 & 593.1 & 13.9 & 0.74 & 14.66 & 16.86 & 1.22 & 2.13 & 96.66 \\
C080 & 508.5 & 9.7 & 0.49 & 20.75 & 17.89 & 0.34 & 0.32 & 99.34 \\
C084 & 853.6 & 12.7 & 0.62 & 11.38 & 17.63 & 0.36 & 1.47 & 98.17 \\
C112 & 486.0 & 10.1 & 0.61 & 8.69 & 13.92 & 6.24 & 0.86 & 92.9 \\
C119 & 461.6 & 10.0 & 0.8 & 14.56 & 16.75 & 0.98 & 0.29 & 98.73 \\
C123 & 446.2 & 12.1 & 0.6 & 13.96 & 15.41 & 1.06 & 0.41 & 98.53 \\
C126 & 379.9 & 8.2 & 0.4 & 10.19 & 14.71 & 3.26 & 0.3 & 96.44 \\
C155 & 471.9 & 7.5 & 0.65 & 30.58 & 21.59 & 1.8 & 0.23 & 97.98 \\
C170 & 441.6 & 6.2 & 0.48 & 24.89 & 23.14 & 13.73 & 0.77 & 83.4 \\
\hline
\end{tabular}

Note: $\mathrm{M}_{\mathrm{ad}}$, Moisture content (as air dry basis); $\mathrm{A}_{\mathrm{ad}}$, Ash content (as air dry basis); $\mathrm{V}_{\mathrm{ad}}$, Volatile matter content, (as air dry basis); $\mathrm{x}$, not analyzed.

Table 2. $R_{o, \text { max }}$ Langmuir parameters and coal structure of the No. 8 coal seam in the Gujiao area

\begin{tabular}{|c|c|c|c|c|c|c|c|c|}
\hline \multirow{2}{*}{$\begin{array}{l}\text { Sample } \\
\text { ID. }\end{array}$} & \multirow{2}{*}{$\begin{array}{c}\text { Coal } \\
\text { lithotype }\end{array}$} & \multirow{2}{*}{ Coal structure } & \multirow{2}{*}{$\begin{array}{c}\mathrm{R}_{\mathrm{o}, \max } \\
(\%)\end{array}$} & \multicolumn{3}{|c|}{ Coal macerals $(\%)$} & \multirow{2}{*}{$\begin{array}{c}\mathrm{P}_{\mathrm{L}} \\
(\mathrm{MPa})\end{array}$} & \multirow{2}{*}{$\begin{array}{c}\mathrm{V}_{\mathrm{L}} \\
\left(\mathrm{m}^{3} / \mathrm{t}\right)\end{array}$} \\
\hline & & & & V & I & M & & \\
\hline E006 & semi-bright & un-deformed & 1.83 & $\mathrm{x}$ & $\mathrm{x}$ & $\mathrm{x}$ & 1.69 & 23.33 \\
\hline C046 & semi-bright & un-deformed & 1.89 & $\mathrm{x}$ & $\mathrm{x}$ & $\mathrm{x}$ & 1.63 & 27.91 \\
\hline W195 & semi-bright & un-deformed & 1.91 & $\mathrm{x}$ & $\mathrm{x}$ & $\mathrm{x}$ & 1.55 & 22.34 \\
\hline DQ8 & semi-bright & un-deformed & 1.85 & 88.6 & 10.4 & 1.0 & $\mathrm{x}$ & $\mathrm{x}$ \\
\hline TL8 & semi-bright & un-deformed & 1.76 & 78.9 & 18.4 & 2.7 & $\mathrm{x}$ & $\mathrm{x}$ \\
\hline ML8 & semi-bright & slight-deformed & 1.96 & 85.6 & 12.9 & 1.5 & $\mathrm{x}$ & $\mathrm{x}$ \\
\hline
\end{tabular}

Note: $\mathrm{V}$, vitrinite; $\mathrm{I}$, inertinite; $\mathrm{M}$, minerals; $\mathrm{P}_{\mathrm{L}}$, Langmuir pressure; $\mathrm{V}_{\mathrm{L}}$, Langmuir volume; $\mathrm{x}$, not analyzed.

Table 3. Statistical data of water type in the Gujiao area

\begin{tabular}{|c|c|c|c|c|c|c|c|c|c|}
\hline \multirow[b]{2}{*}{$\begin{array}{c}\text { Sample } \\
\text { ID }\end{array}$} & \multicolumn{3}{|c|}{ Cation (mg/L) } & \multicolumn{3}{|c|}{ Union (mg/L) } & \multirow[b]{2}{*}{$\begin{array}{c}\mathrm{M} \\
(\mathrm{mg} / \mathrm{L})\end{array}$} & \multirow[b]{2}{*}{$\mathrm{PH}$} & \multirow[b]{2}{*}{$\begin{array}{c}\text { Water } \\
\text { type }\end{array}$} \\
\hline & $\mathrm{K}^{+}$ & $\mathrm{Na}^{+}$ & $\begin{array}{c}\mathrm{Ca}^{2+} \\
+\mathrm{Mg}^{2+}\end{array}$ & $\mathrm{Cl}^{-}$ & $\mathrm{SO}_{4}^{2-}$ & $\begin{array}{l}\mathrm{HCO}_{3}^{-} \\
+\mathrm{CO}_{3}{ }^{2-} \\
\end{array}$ & & & \\
\hline C006 & 5.82 & 1054.64 & 12.09 & 335.68 & 99.20 & 1892.53 & 2512.0 & 8.38 & $\mathrm{NaHCO}_{3}$ \\
\hline $\mathrm{C} 013$ & 3.65 & 914.70 & 8.08 & 136.16 & 52.89 & 1771.01 & 1955.0 & 8.48 & $\mathrm{NaHCO}_{3}$ \\
\hline
\end{tabular}



-57 -

\begin{tabular}{|c|c|c|c|c|c|c|c|c|c|}
\hline C046 & 2.17 & 999.18 & 9.19 & 325.78 & 103.52 & 1774.41 & 2405.0 & 8.69 & $\mathrm{NaHCO}_{3}$ \\
\hline C080 & 1.85 & 483.80 & 10.16 & 121.14 & 33.14 & 1022.81 & 1224.0 & 8.31 & $\mathrm{NaHCO}_{3}$ \\
\hline C112 & 0.94 & 207.60 & 6.83 & 92.58 & 45.48 & 931.50 & 1162.0 & 8.81 & $\mathrm{NaHCO}_{3}$ \\
\hline C119 & 1.31 & 471.87 & 7.44 & 140.12 & 54.54 & 803.59 & 1065.0 & 8.48 & $\mathrm{NaHCO}_{3}$ \\
\hline $\mathrm{C} 123$ & 0.94 & 402.12 & 7.45 & 155.46 & 49.60 & 640.02 & 923.0 & 8.36 & $\mathrm{NaHCO}_{3}$ \\
\hline $\mathrm{C} 126$ & 1.45 & 526.04 & 8.69 & 114.86 & 49.18 & 1041.68 & 1230.0 & 8.49 & $\mathrm{NaHCO}_{3}$ \\
\hline C134 & 1.35 & 359.20 & 6.63 & 136.89 & 19.97 & 718.74 & 906.0 & 7.82 & $\mathrm{NaHCO}_{3}$ \\
\hline C144 & 0.89 & 248.00 & 7.05 & 123.12 & 30.26 & 410.22 & 634.0 & 7.73 & $\mathrm{NaHCO}_{3}$ \\
\hline C153 & 1.14 & 272.20 & 16.07 & 116.22 & 32.31 & 556.00 & 736.0 & 7.97 & $\mathrm{NaHCO}_{3}$ \\
\hline C154 & 0.94 & 231.40 & 9.22 & 111.30 & 35.61 & 450.91 & 632.0 & 7.82 & $\mathrm{NaHCO}_{3}$ \\
\hline C155 & 1.23 & 393.34 & 6.92 & 141.60 & 46.30 & 635.91 & 904.0 & 8.30 & $\mathrm{NaHCO}_{3}$ \\
\hline C170 & 4.71 & 743.14 & 6.73 & 64.85 & 37.25 & 1556.36 & 1570.0 & 8.65 & $\mathrm{NaHCO}_{3}$ \\
\hline E003 & 1.70 & 251.20 & 8.81 & 99.48 & 37.25 & 488.20 & 664.0 & 8.19 & $\mathrm{NaHCO}_{3}$ \\
\hline E026 & 3.95 & 817.13 & 20.32 & 242.60 & 54.12 & 1654.24 & 2027.0 & 8.35 & $\mathrm{NaHCO}_{3}$ \\
\hline E078 & 3.18 & 820.61 & 6.40 & 106.44 & 80.46 & 1564.04 & 1814.0 & 8.56 & $\mathrm{NaHCO}_{3}$ \\
\hline E099 & 2.05 & 273.63 & 11.76 & 101.99 & 47.54 & 1322.86 & 1512.0 & 8.32 & $\mathrm{NaHCO}_{3}$ \\
\hline E143 & 5.02 & 898.17 & 8.26 & 137.64 & 61.94 & 1731.38 & 1966.0 & 8.50 & $\mathrm{NaHCO}_{3}$ \\
\hline E153 & 3.30 & 327.60 & 7.15 & 124.10 & 40.14 & 681.44 & 862.0 & 8.13 & $\mathrm{NaHCO}_{3}$ \\
\hline W012 & 2.97 & 458.00 & 12.04 & 63.03 & 31.48 & 1138.41 & 1192.0 & 8.36 & $\mathrm{NaHCO}_{3}$ \\
\hline W015 & 3.88 & 777.94 & 15.92 & 82.68 & 51.66 & 1560.58 & 1690.0 & 8.47 & $\mathrm{NaHCO}_{3}$ \\
\hline W032 & 0.57 & 156.78 & 35.52 & 52.97 & 53.72 & 413.96 & 510.0 & 7.37 & $\mathrm{NaHCO}_{3}$ \\
\hline W047 & 6.03 & 926.56 & 12.86 & 56.94 & 64.41 & 1931.06 & 2032.0 & 8.49 & $\mathrm{NaHCO}_{3}$ \\
\hline W106 & 4.38 & 872.19 & 4.77 & 56.44 & 63.18 & 1735.74 & 1904.0 & 8.50 & $\mathrm{NaHCO}_{3}$ \\
\hline W118 & 3.57 & 866.85 & 10.64 & 60.90 & 79.64 & 1747.83 & 1930.0 & 8.39 & $\mathrm{NaHCO}_{3}$ \\
\hline W158 & 2.46 & 859.24 & 8.39 & 60.90 & 120.80 & 1724.53 & 1931.0 & 8.44 & $\mathrm{NaHCO}_{3}$ \\
\hline W193 & 4.13 & 743.55 & 13.11 & 49.02 & 61.12 & 1673.69 & 1670.0 & 8.37 & $\mathrm{NaHCO}_{3}$ \\
\hline W200 & 3.09 & 383.03 & 5.68 & 19.30 & 74.30 & 784.00 & 886.0 & 8.43 & $\mathrm{NaHCO}_{3}$ \\
\hline W252 & 3.89 & 710.80 & 9.73 & 72.78 & 64.00 & 1419.85 & 1596.0 & 8.57 & $\mathrm{NaHCO}_{3}$ \\
\hline
\end{tabular}

Note: M, mineralization.

\section{Results and discussions}

\section{Geologic evolution}

\section{Geologic evolution history}

After the Middle and Late Ordovician, the North China platform was overall uplifted due to the Caledonian crustal movements, which resulted in unconformity in the sedimentary record from the Late Ordovician to the Early Carboniferious (Kusky et al., 2007). Subsidence began again in the Middle Carboniferious due to the Hercynian crustal movements and the Permo-Carboniferious coal-bearing strata were deposited during this stage (Yang et al., 2005).

Based on the results in previous research in the XCF (Su et al., 2005; Wang et al., 2007; Sun et al., 2014; Liu et al., 2014), and logging interpretation data, the burial history 
of the Taiyuan formation at CBM wells E006, C046 and W195 were built in the 1D package of Petromod software by back-stripping method in this study. The Taiyuan formation has experienced seven tectonic evolution stages. As can be seen in Figure 5, stage I and stage IV were two slow subsidence stages from the Late Carboniferious to the Late Permian and from the Middle to the Late Jurassic, respectively. Stage II was a rapid subsidence stage from the Late Permian to the Triassic, during which the Taiyuan formation was rapidly buried with the maximum burial depth is about $4000.0 \mathrm{~m}$. This formation was uplifted transitorily and slowly during stage III. Stage V and stage VI were two rapidly uplifting stages, during these two stages, the Taiyuan formation was uplifted and of which the Upper formation was eroded heavily. Stage VII is a stage where uplifting and subsidence have coexisted since the Paleogene. As a result of the evolution of burial history, the present burial depth of the No. 8 coal seam in the Gujiao area ranges from $180.6 \mathrm{~m}$ to $905.8 \mathrm{~m}$.

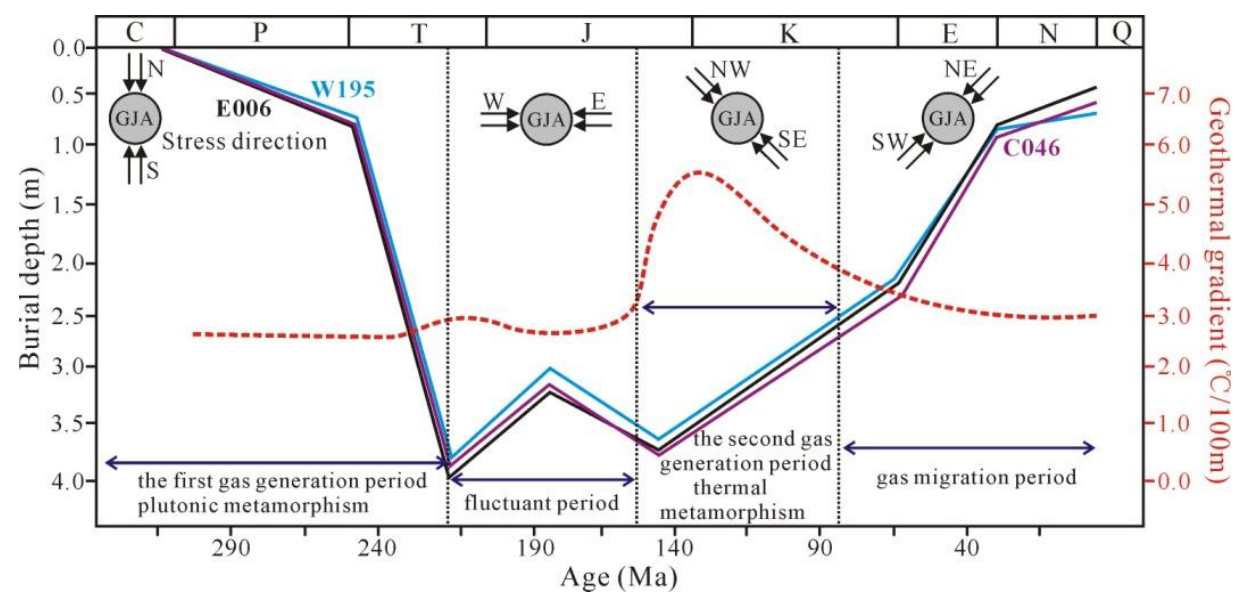

Figure 5. Burial and geothermal gradient curve of the No. 8 coal seam in the Gujiao area (data of red line from Liu et al., 2005).

Before the Yanshanian orogeny movement, the $\mathrm{XCF}$ was a craton basin with a slightly lower geothermal gradient of $2.6{ }^{\circ} \mathrm{C} / 100 \mathrm{~m}-2.9{ }^{\circ} \mathrm{C} / 100 \mathrm{~m}$ (Sun et al., 2014). During the Yanshanian orogeny, which occurred in the early stage $\mathrm{V}$, the igneous intrusions in the south part of the XCF caused abnormal high geothermal gradient $\left(5.0{ }^{\circ} \mathrm{C} / 100 \mathrm{~m}-6.0\right.$ ${ }^{\circ} \mathrm{C} / 100 \mathrm{~m}$ ), and the geothermal gradient has decreased to a normal value after the Yanshanian orogeny movement (Wang et al., 2007).

\section{Evolutionary process of CBM generation and accumulation}

Based on the geologic evolution history of the Taiyuan formation, four periods of gas generation and accumulation can be divided considering the metamorphic types of coal and the preservation condition of CBM. The coal thickness, roof thickness, $\mathrm{R}_{\mathrm{o}}$, max , gas content and proximate components of the No. 8 coal seam in well E006, C046 and W195 were used (Table 1 and 2) to simulate the evolution history of gas content by referenced 
the experiment results in Qin et al., (1997), and the simulation method in Wei et al. (2007 and 2010). The results are shown in Figure 6.
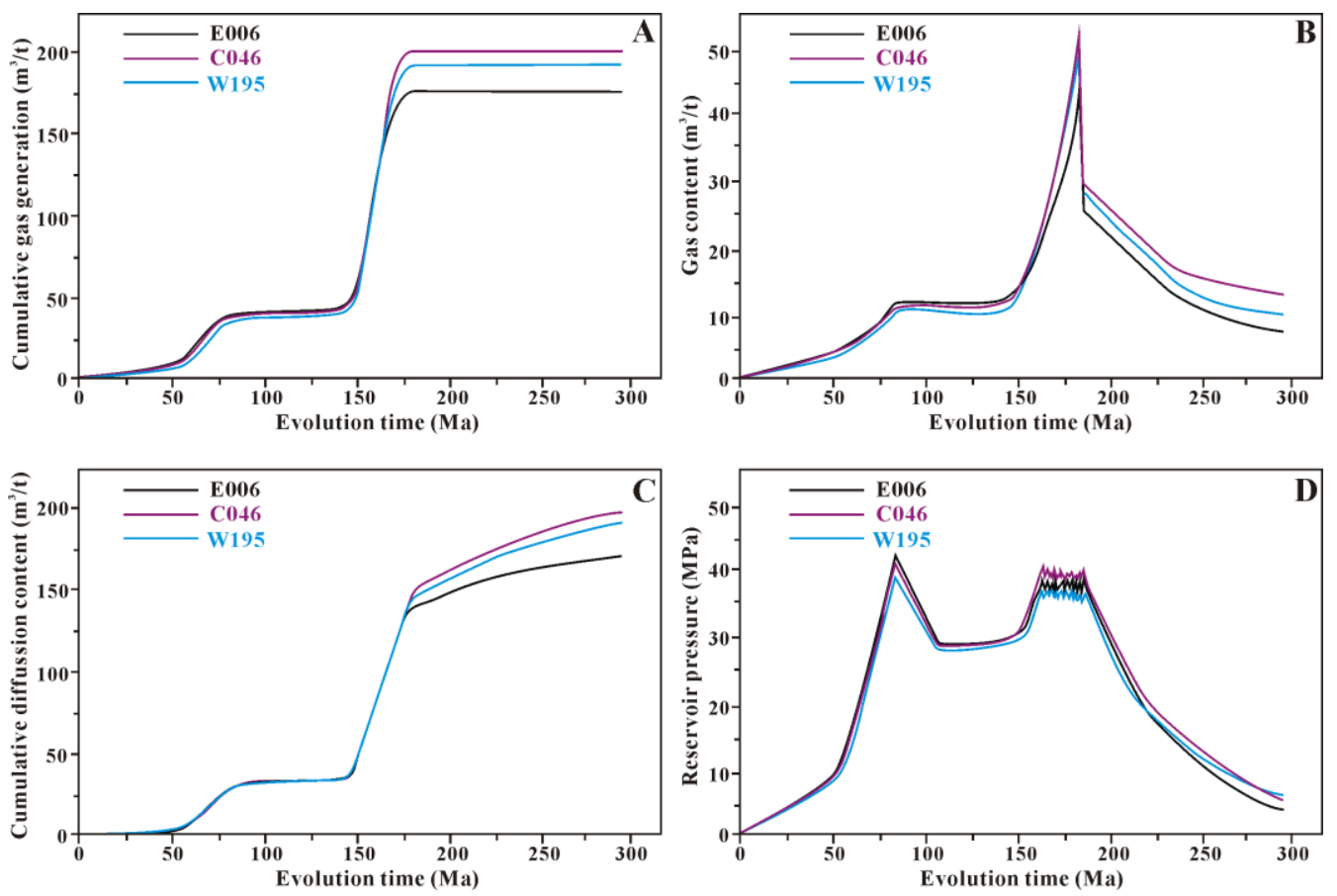

Figure 6. Coalbed methane evolution history curves of the No. 8 coal seam in the Gujiao area.

The first period ranged from the Late Carboniferous to the Triassic (Figure 5), during which the XCF was compressed by the NS trending stress due to the collision between the North China plate and the South China plate (Lin, 1991), and the plutonic metamorphism improved the maturity of coal and generated a certain amount of gas (the first gas generation period) (Liu et al., 2005). The $\mathrm{R}_{\mathrm{o}, \max }$, cumulative gas generation and gas content of the No. 8 coal seam could as higher as $0.70 \%, 50.0 \mathrm{~m}^{3} / \mathrm{t}$ and $15.0 \mathrm{~m}^{3} / \mathrm{t}$, respectively, at the end of this period. The second one was a fluctuant period for gas accumulation, in which the coal rank and cumulative gas generation of the No. 8 coal seam were slightly increased, and the gas content didn't change notably. Owing to the Lvliang uplifting movement under the WE trending stress during this period, the rudiment of the XCF was formed (Guan and Li, 2001). The third period was the second gas generation period from the Late Jurassic to the Early Cretaceous, during which the plutonic metamorphism ended because of the uplifting movements (Wang et al., 2007). However, the thermal metamorphism caused by the igneous intrusion improved greatly the coal rank of the No. 8 coal seam, and a great amount of gas was generated. The $\mathrm{R}_{\mathrm{o} \text {, max }}$, cumulative gas generation and gas content of the No. 8 coal seam could reach $2.00 \%$, $200.0 \mathrm{~m}^{3} / \mathrm{t}$ and $30.0 \mathrm{~m}^{3} / \mathrm{t}$, respectively. The last period is the gas migration period since the Late Cretaceous, during which, continuously uplifting movements destroyed the gas equilibrium again and again owing to the release of overburden stress (Su et al., 2005). As 
a result, the coalification and gas generation are ended, and the previous gas is desorbed and migrated. The residual gas content in the No. 8 coal seam ranges from $4.0 \mathrm{~m}^{3} / \mathrm{t}$ to 16.5 $\mathrm{m}^{3} / \mathrm{t}$. The Jinzhong and Taiyuan grabens developed during this period because the effects of the Himalaya orogeny, and these two grabens separated the XCF from the Qinshui basin completely (Fu, 2008).

The geologic evolution history has determined the coal rank, gas generation and migration, but could not individually explain the present distribution of gas content, because which is affected by various parameters, especially by structural form, burial depth and hydrodynamic condition (Bustin and Clarkson, 1998; Jiang et al., 2010; Wang et al., 2013), and hydrodynamic condition and burial depth are controlled by structural form (Cai et al., 2014; Meng et al., 2014c).

\section{Structural geometry}

\section{Structural geometry characteristics}

The structural map of the No. 8 coal seam in the Gujiao area was drew (Figure 7) based on the data of coalmining geology and CBM well-logging interpretation, and previous research (Guan and Li, 2001; Fu, 2008; Wang et al., 2015a), which reflects that the Gujiao area is a NS axial striking syncline (Malan syncline). The structural geometry of the east wing of the Malan syncline is far different with the west one. The east wing is a gentle monocline including many large normal faults with average dip angle is $4.6^{\circ}$. However, the west wing is a steep monocline containing many secondary folds with average dip angle is $24.5^{\circ}$. According to the completely different structural characteristics between the two wings of the Malan syncline, the Gujiao area has been subdivided into two subareas (subarea A distributes in the west wing and B in the east) by the axial of the Malan syncline. Burial depth and water level are two structure-dominated parameters, and usually higher elevation corresponds to shallower burial depth and higher water level, and vice versa (Perrier and Quiblier, 1974).

\section{Structural form and gas content}

The CBM is mainly adsorbed in the coal matrix, only a little CBM (less than $10 \%$ ) are free or dissolved gases (Bustin and Clarkson, 1998). The structural deformations of coal seams during geologic evolution have released the tectonic stress and then the adsorbed gas has been desorbed and migrated (Meng et al., 2014a). As a result, the gas content in the coal seams decreases continuously. The No. 15 coal seam in the SQB has nearly same rank, composition and burial depth with the No. 8 coal seam in the XCF, however, the gas content of the No. 15 coal seam is much higher than the No.8 (Lv et al., 2012; Wang et al., 2015a) duo to that the SQB is a relatively complete and uniform tectonic block, and the $\mathrm{XCF}$ is much complicate and multiform. The tectonic stress from the east to the west on the Gujiao area during the Early Yanshanian orogeny creates the Malan syncline, and because the obstruction of the Lvliang mountain, the subarea A was the passive region and deformed heavily. However, the subarea B was the driving region and in which the 
plastic deformations were few but brittle fractures were developed (Gui, 1986). As a result, the subarea $\mathrm{B}$ is a relatively uniform block and the subarea $\mathrm{A}$ is a multiform block in the Gujiao area.

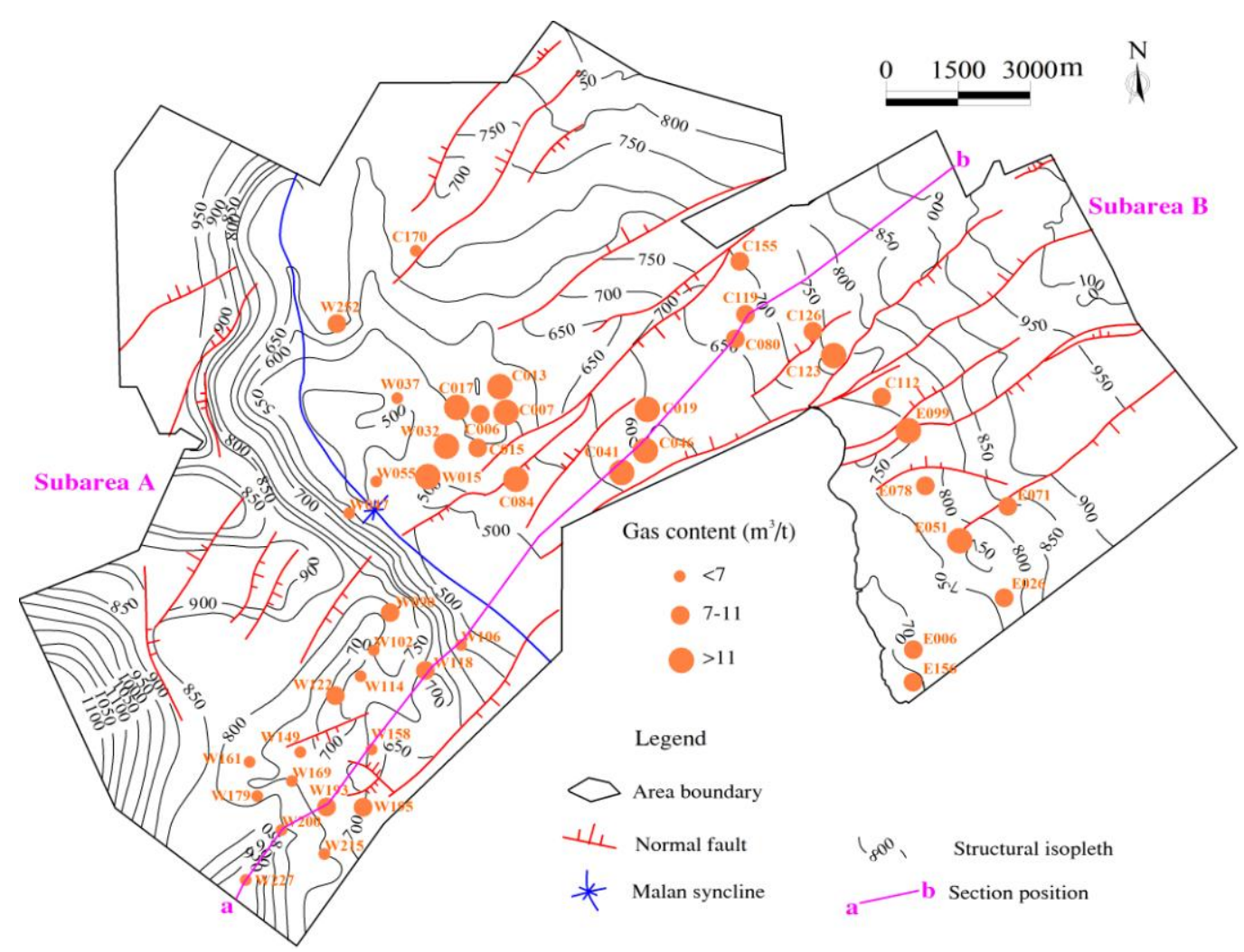

Figure 7. Structural top of the No. 8 coal seam in the Gujiao area (structural map was drew based on the coalmining geology data in the goaf area, CBM-well logging interpretation data in CBM-producing area).

Gas content of coal is dominated by many parameters, among which coal composition has been considered to be the most important one. Coal with higher fixed carbon content has stronger adsorption capacity and better gas generation potential (Walker et al., 2001). In the Gujiao area, the relation between composition and gas content of the No. 8 coal seam is weak due to the effect of structural form. As documented in Table 4, the No. 8 coal seam in the subareas A and B have similar average composition and burial depth, however, the average gas content in the subarea $B\left(10.7 \mathrm{~m}^{3} / \mathrm{t}\right)$ is much higher than that in the subarea $\mathrm{A}\left(6.4 \mathrm{~m}^{3} / \mathrm{t}\right)$. The severe structural deformation in the subarea A caused that a large amount of gas was desorbed and migrated. Sedimentary parameters (including coal composition and thickness) mainly determine the gas-generating potential (Yao et al., 2014), and the present actual gas content mainly depends on the tectonic evolution history and structural form. Moreover, the adsorbability of main gases is in the order of $\mathrm{CO}_{2}>$ $\mathrm{CH}_{4}>\mathrm{N}_{2}$, and the stress release caused by structural deformation will increase the content of gas which has weak adsorbability. 
Table 4. The average composition, burial depth and gas content of the subarea A and B in the Gujiao area

\begin{tabular}{ccccccccc}
\hline \multirow{2}{*}{ Subarea } & Burial depth & Gas content & \multicolumn{3}{c}{ Proximate analysis (\%) } & \multicolumn{3}{c}{ Gas composition (\%) } \\
\cline { 5 - 9 } & $(\mathrm{m})$ & $\left(\mathrm{m}^{3} / \mathrm{t}\right)$ & $\mathrm{M}_{\mathrm{ad}}$ & $\mathrm{A}_{\mathrm{ad}}$ & $\mathrm{FC}_{\mathrm{ad}}$ & $\mathrm{N}_{2}$ & $\mathrm{CO}_{2}$ & $\mathrm{CH}_{4}$ \\
\hline $\mathrm{A}$ & 619.9 & 6.4 & 0.76 & 23.56 & 54.30 & 9.53 & 1.09 & 88.60 \\
$\mathrm{~B}$ & 604.6 & 10.7 & 0.62 & 18.47 & 62.57 & 4.62 & 1.04 & 94.15 \\
\hline
\end{tabular}

Note: $\mathrm{M}_{\mathrm{ad}}$, Moisture content (as air dry basis); $\mathrm{A}_{\mathrm{ad}}$, Ash content (as air dry basis); $\mathrm{V}_{\mathrm{ad}}$, Volatile matter content, (as air dry basis).

\section{Faults and gas content}

As with structural deformation, fault is the result of stress release, which will induce the gas desorption and migration (Pashin and Groshong Jr, 1998). The effect of structural deformation on gas content is broad since the deformation is a large-area action, however, the effect of fault on gas content is local, which only distribute near fault. Which have induced that the subarea B still has much higher gas content than the subarea A even though many large normal faults developed in the subarea B. The faults in the Gujiao area were mainly induced by NE directional tensile stress (Guan and Li, 2001), however, these tensile faults were subsequently closed under NE directional compressive stress, and these activities were clearly recorded by the cleavages (Figure 9). Closed faults have prevented the gas migration and are helpful for preserving gas. As a result, the gas content near the faults in the Gujiao area hasn't decreased notably (Figure 7).

\section{The effects of burial depth on gas content}

Great number of papers and reports in various CBM-producing basins around the world show that the gas content increases with the increasing burial depth in the shallow buried area, but decreases with the burial depth increasing in the deep buried area (Bustin and Clarkson, 1998; Faiz et al., 2007; Wang et al., 2013; Cai et al., 2014). The coal reservoir pressure usually increases with the increasing burial depth. On the one hand the increasing pressure will improve the adsorption capacity of the coal reservoir, but on the other which will change the matrix and pore structure of it when the pressure is high enough and then decrease its' adsorption capacity (Xiang et al., 2011; Li et al., 2015). The distribution of the burial depth of the No. 8 coal seam in the Gujiao area can be seen in Figure 10A, which reflects that the burial depth inclines to increase from the wings to core of the Malan syncline. In the Gujiao area, as can be seen in Figure 11A, the relation between burial depth and gas content of the No. 8 coal seam is much complicate and irregular compared with that in the SQB (Lv et al., 2012) and EOB (Cai et al., 2014). However, when considering the subarea B individually, the relation between burial depth and gas content still notable and the critical burial depth is about $600.0 \mathrm{~m}$. It is odd, and hasn't been mentioned and explained by previous studies.

Structural form has superposed effect on gas content. Theoretically, the gas content in syncline region is higher than that in anticline region because syncline has relative deeper 
burial depth and higher reservoir pressure than anticline (Faiz et al., 2007). However, the core regions of syncline and anticline have been deformed severely, as a result, the flank regions of syncline and anticline tend to have higher gas content. The relation between gas content and burial depth has been weakened by structural form in the subarea A. The subarea B is a gentle monocline, in which the structural form is uniform, so the effect of burial depth on gas content can be reflected.

\section{The effects of hydrodynamic condition on gas content}

Hydrodynamic condition is one of the most important parameters dominating the distribution of gas content (Meng et al., 2014c). In strong runoff area, flowing underground water will take the dissolved gas and free gas away. To maintain the dynamic balance among adsorbed gas, dissolved gas and free gas, adsorbed gas will partly desorbed and become dissolved gas and free gas (Wang et al., 2015b). As a result, the gas content will decrease gradually in strong runoff area. The stronger the hydrodynamic force is, the lower the gas content has been retained. In stagnant area, the hydrostatic column pressure improved the coal reservoir pressure and adsorption capacity, which is helpful to preserve gas.

Runoff area and stagnant area are relative concepts. To reflect the hydrodynamic characteristics in the Gujiao area, equivalent water level was calculated by referencing reduced water level formula in Wang et al. (2015b), based on the data of the No. 8 coal reservoir pressure measured in production practice. The result shows that the water level ranges from $648.0 \mathrm{~m}$ to $1187.0 \mathrm{~m}$ and the main hydrodynamic flowing direction is parallel to the dip direction of the coal-bearing formation (Figure 8). The core of the Malan syncline is the main catchment area, and in the wings the water level decreases with increasing elevation of the No. 8 coal seam (Figure 10B). Chemical composition analyses of water samples reflect that they are $\mathrm{NaHCO}_{3}$ type, and the mineralization ranges from $510 \mathrm{mg} / \mathrm{L}$ to $2512 \mathrm{mg} / \mathrm{L}$ (Table 3). Water mineralization has close relation with water level. As can be seen in Figure 8, high mineralization distributes in the low water level region and vice versa.

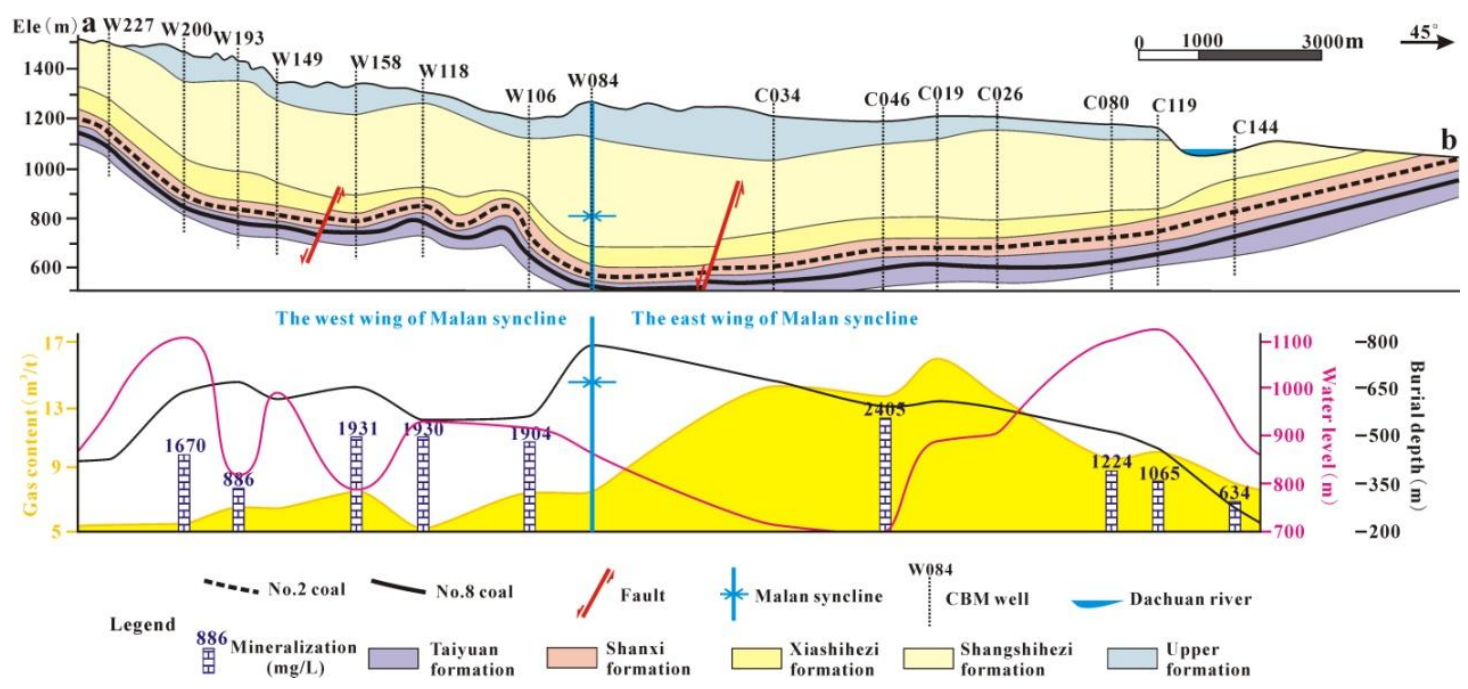

Figure 8. Well section in Gujiao area showing burial depth, gas content of the No. 8 coal seam 


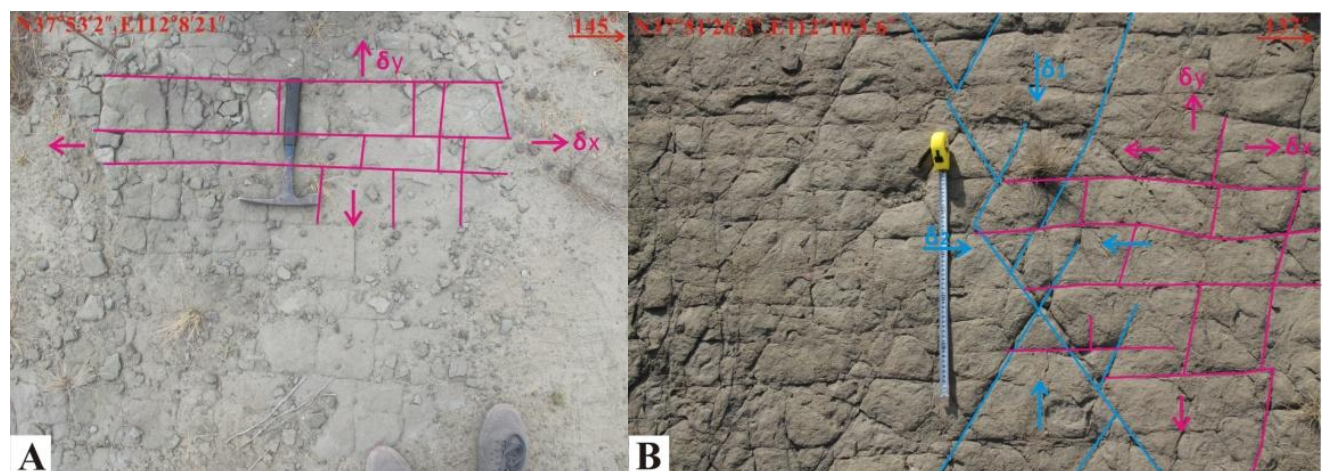

Figure 9. Field pictures of cleavages in the XCF. (A) Outside the Gujiao area. (B) In the Gujiao area.
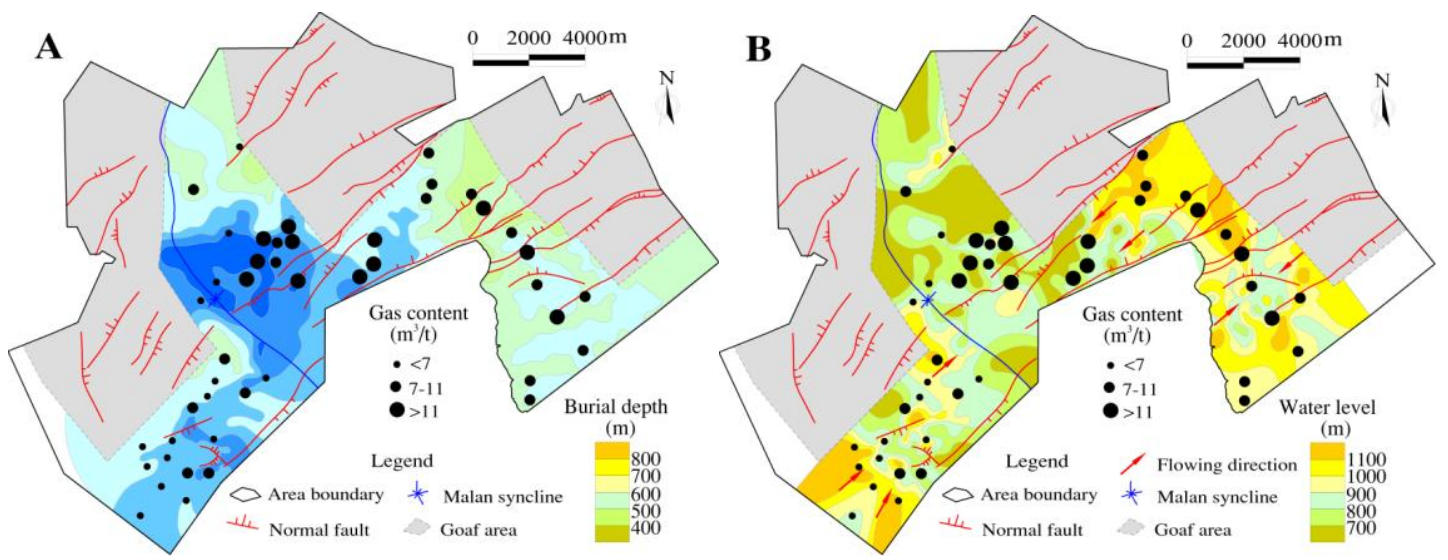

Figure 10. (A) The burial depth isopleths map of the No.8 coal seam. (B) The water level isopleths map
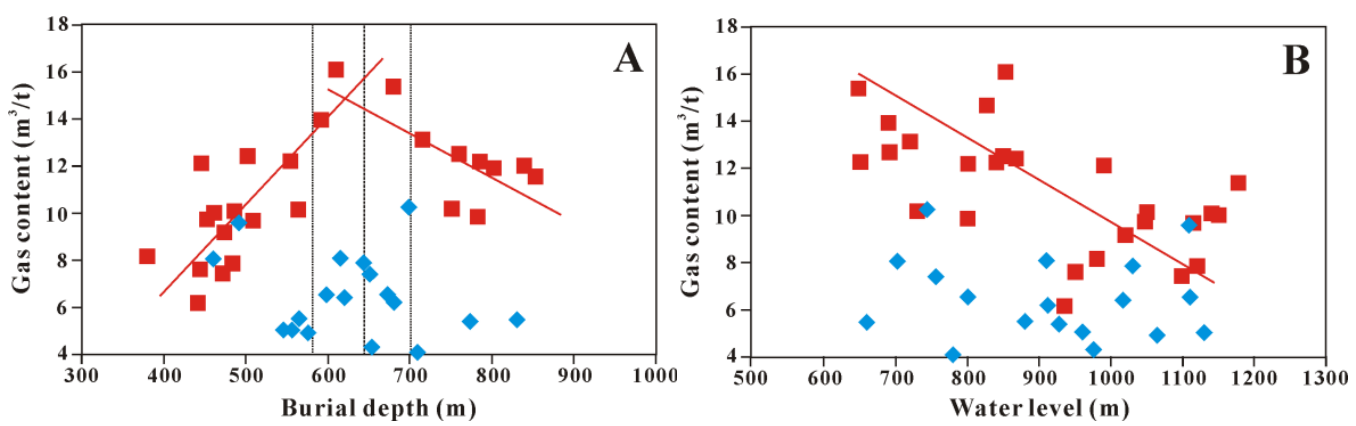

Figure 11. (A) Relationship between burial depth and gas content. (B) Relationship between water level and gas content.

The relation between water level and gas content is shown in Figure 11B. In the subarea B, the gas content decreases with the increasing water level. However, their relation is weak in the subarea A because the superposed effect from structural form. In the Gujiao area, the gas content is less than $10.0 \mathrm{~m}^{3} / \mathrm{t}$ when the water level is higher than 
$1000.0 \mathrm{~m}$, and more than $12.0 \mathrm{~m}^{3} / \mathrm{t}$ when it is lower than $900.0 \mathrm{~m}$, and which reflect that weak hydrodynamic force is more favorable for gas preservation.

\section{"Sweet spots" for CBM development}

In the Gujiao area, based on the analyses in section 4.2, it can be concluded that gentle monocline is much helpful for preserving gas compared with deformed subarea and the effect of faults on gas content is weak because these faults are closed. Regions with burial depth from $500.0 \mathrm{~m}$ to $800.0 \mathrm{~m}$ and water level lower than $900.0 \mathrm{~m}$ are favorable regions for producing CBM. According to the effects of structural form, burial depth and hydrodynamic condition on the gas content of the No. 8 coal seam, the "sweet spots" of CBM development in the Gujiao area were recognized and showed in Figure 12, which will be instructive for CBM development and instructing CBM development plan in the Gujiao area.

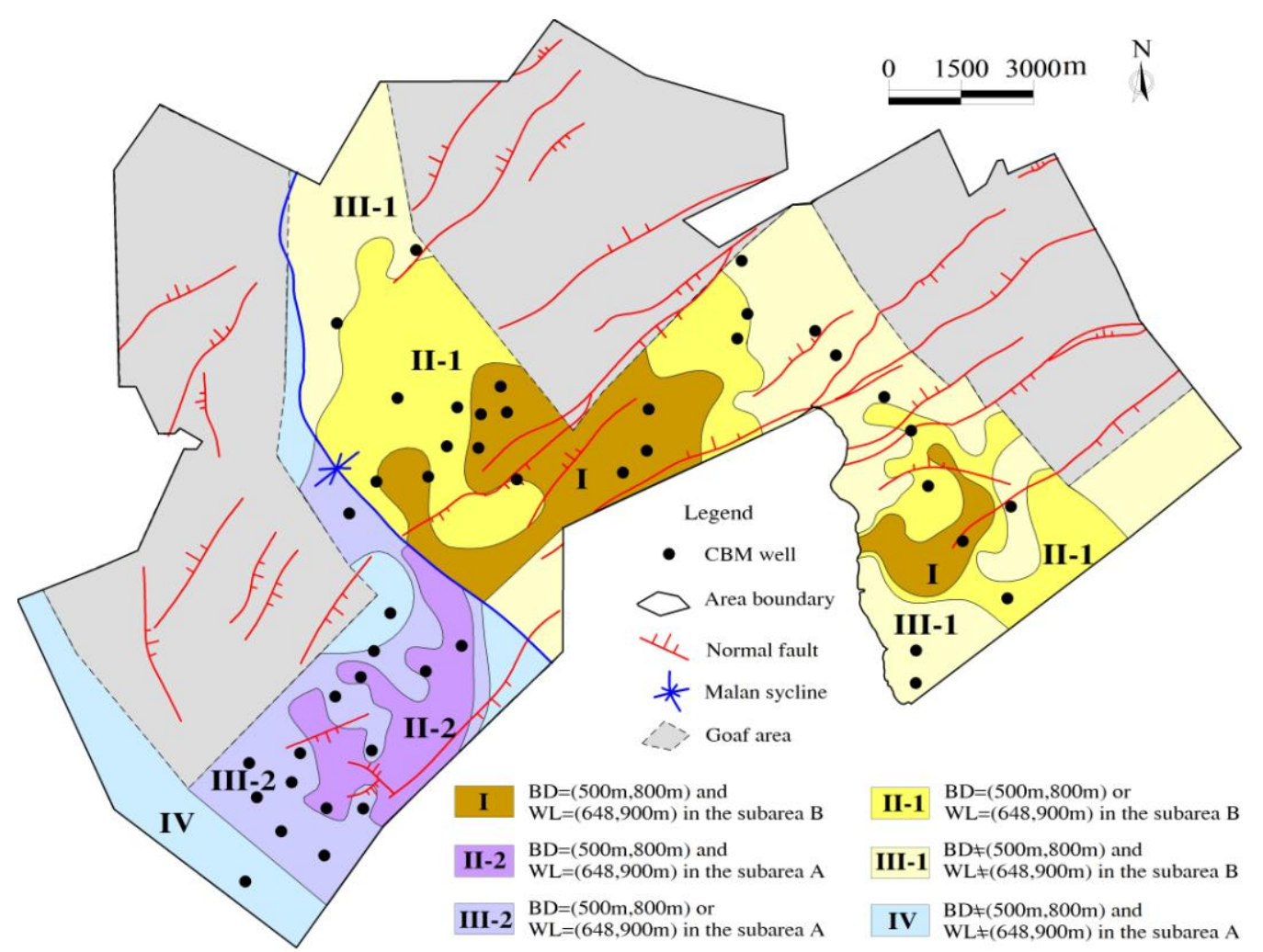

Figure 12. Evaluation regions for CBM concentration potential and trapping classification of the No. 8 coal seam in the Gujiao area

A total of 6 types of regions were subdivided (Figure 12). The type I blocks are the most prospective blocks, and the type II-1 and II-2 blocks take second place. The type III-1, III-2 and IV blocks are deemed to be unfit for CBM development, and the type I, II-1 and II-2 blocks are "sweet spots" in the Gujiao area. 


\section{Conclusions}

In the Gujiao area, the No. 8 coal seam experienced two gas-generating periods and one fluctuant period, and has entered migration period since the Late Cretaceous. The distribution of gas content of the No. 8 coal seam in the Gujiao area is mainly dominated by structural form, water level and burial depth, all which are structural related parameters. The gas content in the subarea $\mathrm{A}$ is much lower than that in the subarea $\mathrm{B}$ because the subarea A is deformed severely and the subarea B is a gentle monocline. The gas content first increases and then decreases with increasing burial depth, and the turning burial depth is about $600 \mathrm{~m}$. Strong runoff area is harmful for preserving gas due to the washing effect in it. The analyzing results show that: gentle and simple monocline blocks with burial depth ranges from $500.0 \mathrm{~m}$ to $800.0 \mathrm{~m}$, water level lower than $900.0 \mathrm{~m}$ is the most important "sweet spots" for CBM development.

Acknowledgements. This work was funded by the Key Project of Coal-based Science and Technology in Shanxi Province (Grant no. MQ2014-01), the National Natural Science General Program (Grant no. 41372165), Shanxi Province Science Foundation for Youths (Grant no. 2015021171) and Shanxi Province Joint Research Fund of Coalbed Methane (Grant no. 2015012007). Moreover, the authors are grateful to the editor and anonymous reviewers of this paper, and Ms. Sarah Enslow at Taiyuan University of Technology for their assistance in the revision of the manuscript.

\section{REFERENCES}

[1] Boreham, C.J., Golding, S.D., Glikson, M. (1998): Factors controlling the origin of gas in Australian Bowen basin coals. - Organic Geochemistry 29(1-3): 347-362.

[2] Bustin, R.M., Clarkson, C.R. (1998): Geologic controls on coalbed methane reservoir capacity and gas content. - International Journal of Coal Geology 38: 3-26.

[3] Cai, Y.D., Liu, D.M., Zhang, K.M., Elsworth, D., Yao, Y.B., Tang, D.Z. (2014): Preliminary evaluation of gas content of the No. 2 coal seam in the Yanchuannan area, southeast Ordos basin, China. - Journal of Petroleum Science and Engineering 122: 675-689.

[4] Faiz, M., Saghafi, A., Sherwood, N., Wang, I. (2007): The influence of petrological properties and burial history on coal seam methane reservoir characterization, Sydney basin, Australia. - International Journal of Coal Geology 70: 193-208.

[5] Fu, J.H. (2008): Development mechanism and influence analysis of Xishan coal field geologic structure. - Shanxi Coking Coal Science and Technology (Chinese Edition) 6: 17-19.

[6] Guan, Y.B., Li, H.M. (2001): The tectonic evolution of Taiyuan district. J. - Liaoning Technical University (Natural Science) (Chinese Edition) 20(1): 32-35.

[7] Gui, X.Z. (1986): Study on mechanism of NE-NEE faults in the south part of Xishan coalfield, Taiyuan, Shanxi. - Shanxi Geology (Chinese Edition) (2): 151-161.

[8] Jiang, B., Qu, Z.H., Wang, G.G.X., Li, M. (2010): Effects of structural deformation on formation of coalbed methane reservoirs in Huaibei coalfield, China. - International Journal of Coal Geology 82: 175-183.

[9] Johnson, R.C., Flores, R.M. (1998): Developmental geology of coalbed methane from shallow to deep in Rocky Mountain basins and in Cook Inlet-Matanuska basin, Alaska, U.S.A. and Canada. - International Journal of Coal Geology 35: 214-282.

[10] Karacan, C. Ö. (2009) Reservoir rock properties of coal measure strata of the Lower 
Monongahela Group, Greene County (Southwestern Pennsylvania), from methane control and production perspectives. - International Journal of Coal Geology 78: 47-64.

[11] Kusky, T.M., Windley, B.F., Zhai, M.G. (2007): Tectonic evolution of the North China block: from orogen to craton to orogeny. - Geologic Society 280: 1-34.

[12] Li, X., Zeng, F.G., Wang, W., Dong, K., Cheng, L.Y. (2015): FTIR characterization of structural evolution in low-middle rank coals. - Journal of China Coal Society (Chinese Edition) 40(12): 2900-2908.

[13] Lin, J.P. (1991): The tectonic stress field in the Mesozoic of Shanxi province. Geoscience (Chinese Edition) 5(4): 355-364.

[14] Liu, C., Sun, B.L., Zeng, F.G. (2014): Constraints on U-Pb dating of detrital zircon of the maximum depositional age for Upper Permian to Lower Triassic strata in Xishan, Taiyuan. - Acta Geologica Sinica (Chinese Edition) 88(8): 1579-1587.

[15] Liu, H.L., Wang, H.Y., Zhao, G.L., Li, G.Z., Yang, F., Liu, H.J. (2005): The effects of tectonic thermal events in Yanshanian period on the accumulation of coalbed methane in the Gujiao area. - Natural Gas Industry (Chinese Edition) 5(1): 29-32.

[16] Lv, Y.M., Tang, D.Z., Xu, H., Luo, H.H. (2012): Production characteristics and the key factors in high-rank coalbed methane field: A case study on the Fanzhuang block, Southern Qinshui basin, China. - International Journal of Coal Geology 96-97: 93-108.

[17] Meng, Y.J., Tang, D.Z., Xu, H., Li, C., Li, L., Meng, S.Z. (2014b): Geologic controls and coalbed methane production potential evaluation: A case study in Liulin area, eastern Ordos basin, China. - Journal of Natural Gas Science and Engineering 21: 95-111.

[18] Meng, Y.J., Tang, D.Z., Xu, H., Li, Y., Gao, L.J. (2014c): Coalbed methane produced water in China: status and environmental issues. - Environmental Science and Pollution Research 21: 6964-6974.

[19] Meng, Y.J., Tang, D.Z., Xu, H., Qu, Y.J., Li, Y., Zhang, W.Z. (2014a): Division of coalbed methane desorption stages and its significance. - Petroleum Exploration and Exploitation 41(5): 671-677.

[20] Pang, J.D., Wang, L., Zang, X.L., Tang, D.Z., Zhao, Y.B., Li, J.J., Zhu, W.Q. (2015): The coalbed methane resource in the Gujiao area. - Science Technology and Engineering (Chinese Edition) 15(33): 155-160.

[21] Pashin, J.C., Groshong Jr, R.H. (1998): Structural control of coalbed methane production in Alabama. - International Journal of Coal Geology 38: 89-113.

[22] Payne, D.F., Ortoleva, P.J. (2001): A model for lignin alteration-part II: numerical model of natural gas generation and application to the Piceance basin, Western Colorado. Organic Geochemistry 32: 1087-1101.

[23] Perrir, R., Quiblier, J. (1974): Thickness changes in sedimentary layers during compaction history; methods for quantitative evaluation. - AAPG Bull 58(3): 507-520.

[24] Qin, Y., Song, D.Y., Wang, C. (1997): Coalification of the Upper Paleozoic coal and its control to the generation and preservation of coalbed methane in the southern Shanxi. Journal of China Coal Society (Chinese Edition) 22(3): 230-235.

[25] Scott, A.R., Kaiser, W.R., Ayers Jr., W.B. (1994): Thermogenic and secondary biogenic gases, San Juan Basin, Colorado and New Mexico-implications for coalbed methane productivity. - AAPG Bull 78: 1186-1209.

[26] Song, Y., Liu, S.B., Zhang, Q., Tao, M.X., Zhao, M.J., Hong, F. (2012): Coalbed methane genesis, occurrence and accumulation in China. - Petroleum Science 9: 269-280.

[27] Su, X.B., Lin, X.Y., Zhao, M.J., Song, Y., Liu, S.B. (2005): The upper Paleozoic coalbed methane system in the Qinshui basin, China. - AAPG Bull 89(1): 81-100.

[28] Sun, B.L., Zeng, F.G., Liu, C., Cui, X.Q., Wang, W. (2014): Constraints on U-Pb dating of detrital Zircon of the maximum depositional age for upper Paleozoic coal-bearing strata in Xishan, Taiyuan, and Its stratigraphic significance. - Acta Geologica Sinica (Chinese Edition) 88(2): 185-195. 
[29] Walker, R., Glikson, M., Mastalerz, M. (2001): Relations between coal petrology and gas content in the Upper Newlands Seam, central Queensland, Australia. - International Journal of Coal Geology 46: 83-92.

[30] Wang, B., Jiang, B., Guo, Z.B., Liu, H.L., Wang, H.Y., Li, G.Z., Zhao, Q. (2007): Coalbed methane reservoir features in the Xishan coal field, Qinshui basin. - Natural Gas Geoscience (Chinese Edition) 18(4): 565-567.

[31] Wang, B., Sun, F.J., Tang, D.Z., Zhao, Y., Song, Z.H., Tao, Y. (2015b): Hydrological control rule on coalbed methane enrichment and high yield in FZ Block of Qinshui Basin. - Fuel 140: 568-577.

[32] Wang, B., Xu, F.Y., Jiang, B., Chen, W.Y., Li, M., Wang, L.L. (2013): Studies on main factor coupling and its control on coalbed methane accumulation in the Qinshui Basin. Energy Exploration \& Exploitation 31(2): 167-186.

[33] Wang, G., Qin, Y., Xie, Y.W., Shen, J., Han, B.B., Huang, B., Zhao, L. (2015a): The division and geologic controlling factors of a vertical superimposed coalbed methane system in the northern Gujiao blocks, China. - Journal of Natural Gas Science and Engineering 24: 379-389.

[34] Wei, C.T., Qin, Y., Wang, G.G.X., Fu, X.H., Jiang, B., Zhang, Z.Q. (2007): Simulation study on evolution of coalbed methane reservoir in Qinshui basin, China. - International Journal of Coal Geology 72: 53-69.

[35] Wei, C.T., Qin, Y., Wang, G.G.X., Fu, X.H., Zhang, Z.Q. (2010): Numerical simulation of coalbed methane generation, dissipation and retention in SE edge of Ordos Basin, China. - International Journal of Coal Geology 82: 147-159.

[36] Xia, P., Zeng, F.G., Song, X.X. (2016): Parameters controlling high-yield coalbed methane vertical wells in the B3 area, Xishan coal field, Shanxi, China. - Energy Exploration \& Exploitation 34(5): 711-734.

[37] Xiang, J.H., Zeng, F.G., Liang, H.Z., Sun, B.L., Zhang, L., Li, M.F., Jia, J.B. (2011): Model construction of the macromolecular structure of Yanzhou coal and its molecular simulation. - Journal of Fuel Chemistry and Technology (Chinese Edition) 39(7): 481-488.

[38] Yang, Y., Li, W., Ma, L. (2005): Tectonic and stratigraphic controls of hydrocarbon systems in the Ordos basin: a multicycle cratonic basin in the central China. - AAPG Bull 89(2): 255-269.

[39] Yao, Y.B., Liu, D.M., Xie, S.B. (2014): Quantitative characterization of methane adsorption on coal using a low-field NMR relaxation method. - International Journal of Coal Geology 131: 32-40.

[40] Zhang, S.H., Tang, S.H., Tang, D.Z., Pan, Z.J., Yang, F. (2010): The characteristics of coal reservoir pores and coal facies in Liulin district, Hedong coal field of China. International Journal of Coal Geology 81: 117-127.

[41] Zhao, J.L., Tang, D.Z., Xu, H., Lv, Y.M., Tao, S. (2015): High production indexes and the key factors in coalbed methane production: A case in the Hancheng block, southeastern Ordos basin, China. - Journal of Petroleum Science and Engineering 130: 55-67. 